EDITORIAL

https://doi.org/10.31688/ABMU.2020.55.2.203

\author{
Hongyun WANG ${ }^{1,2}$, Xinyue $\mathrm{ZHU}^{2}$, Junjie XIAO ${ }^{1,2} \square$ \\ ${ }^{1}$ Cardiac Regeneration and Ageing Lab, Institute of Cardiovascular Sciences, School of Medicine, Shanghai \\ University, Shanghai, China \\ ${ }^{2}$ Cardiac Regeneration and Ageing Lab, Institute of Cardiovascular Sciences, School of Life Science, \\ Shanghai University, Shanghai, China
}

\section{ENGINEERED EXTRACELLULAR VESICLES AND NANOPARTICLES: PROMISING TOOLS FOR DISEASE TREATMENT}

Living forever is a beautiful vision that human being has been pursuing. With the development of science and technology, an increasing number of approaches have been emerging for repairing and regenerating the damaged organs, such as cell therapy, gene therapy and transplant etc. However, the side effects of these methods limit their clinical use. For example, myoblast transplantation leads to an increase in number of early postoperative arrhythmic events ${ }^{1}$. Therefore, it has a long way to use these approaches for clinical therapy in a short-term and it is urgent to look for secure effective strategies. Recently, extracellular vesicles (EVs) have attracted extensive interests as a potential therapeutic strategy of diseases such as cancer, cardiovascular diseases etc. A growing number of investigations demonstrate that various engineered EVs can repair the damaged tissue in vivo ${ }^{2}$.

This editorial highlights 6 selected papers dedicated to the engineered extracellular vesicles as well as nanoparticles, including: 1) classical strategies for modifying EVs; 2) the roles of engineered $\mathrm{EV}_{\mathrm{s}}$ in

\section{TECHNIQUES D'INGENIERIE ARTIFICIELLE DES VÉSI- CULES ET DES NANOPARTI- CULES EXTRACELLULAIRES; DES OUTILS PROMETTEURS POUR LE TRAITEMENT DES MALADIES}

Vivre pour toujours est une belle vision que l'être humain poursuit. Avec le développement de la science et de la technologie, un nombre croissant d'approches ont émergé pour réparer et régénérer les organes endommagés, comme la thérapie cellulaire, la thérapie génique et la transplantation, etc. Cependant, il existe différentes limites à l'utilisation clinique de ces méthodes, en raison d'effets secondaires potentiels. Par exemple, la transplantation de myoblastes conduit à une augmentation du nombre d'événements arythmiques postopératoires précoces ${ }^{1}$. Par conséquent, c'est un long chemin à utiliser ces approches pour la thérapie clinique à court-terme et urgent de rechercher des stratégies efficaces sécurisées. Récemment, les vésicules extracellulaires (VE) ont suscité un intérêt considérable en tant que stratégie thérapeutique potentielle de maladies telles que

$\triangle$ Correspondence address: Junjie XIAO

Cardiac Regeneration and Ageing Lab, Institute of Cardiovascular Sciences, School of Medicine, Shanghai University

Address: 333 Nan Chen Road, Shanghai 200444, China

E-mail: junjiexiao@shu.edu.cn; Phone 0086-21-66138131; Fax: 0086-21-66138131 
treatment. Besides, the outlook for engineered EVs has been briefly discussed.

To improve the efficiency of EVs as well as targeted tissue retention, several investigations were performed. Kyle et al firstly used a cardiomyocytes specific peptide (CMP) to make the cardiac-targeted $\mathrm{EV}^{3}$. It was then verified that the modified EVS (CMP- EVs) can be specifically taken up by cardio-myocytes both in vitro and in vivo. This approach laid the foundation for cell and cardiac-specific EVs delivery, which gives a reference for studying targeted-EV. Interestingly, Tang et al came up with a novel idea based on the recruitment of platelets by injured endothelial cells ${ }^{4}$. These authors decorated platelet-microvesicles (inside of platelet, similar with EVs) on the surface of cardiosphere-derived cardiac stem cells (CSCs), which significantly increased the retention in the heart. This manipulation approach is safe and straightforward, which opens novel insights into targeted-EVs for therapy. Recently, Liming et al used an adhesive hydrogel to enhance the retention of $\mathrm{EVs}^{5}$. The EVs were immobilized in an adhesive hydrogel (Exo-pGel) and the encapsulated-EVs can stay at the injured area. The Exo-pGel presents a promising strategy for preclinical treatment.

It has been well established that the engineered $E V_{s}$ have great potential for disease treatment in animal models. Vandergriff et al systemically investigated the role of CMP- EVs in cardiac dysfunction treatment. The authors found that EVs conjugated with cardiac homing peptide (CHP, similar with $\mathrm{CMP}$ ) can protect heart from ischemia/reperfusion injury owing to their increased retention ${ }^{6}$. This work demonstrates a novel approach for increasing delivery of myocardial infarction treatment. Liu et al reported that EVs loading with novel complex hydrogels can promote wounds healing, which provides another effective hydrogel strategy for engineering $\mathrm{EVs}^{\mathrm{7}}$. Li et al investigated the roles of Exo-pGel in treatment of spinal cord injury. The Exo-pGel significantly promoted nerve recovery via inhibiting oxidative stress and inflammation ${ }^{5}$. Besides, Chuanjiang $\mathrm{He}$ et al give an insight into how $\mathrm{EV}$ s engineered as powerful tools in translational medicine $e^{8}$.

In conclusion, there are strategies for engineering $\mathrm{EV}$ s/nanoparticles, with potential roles in disease treatment. Notably, more preclinical investigations and clinical trials are still needed to elucidate the possibility of engineered EVs and nanoparticles in human diseases treatment. le cancer, les maladies cardio-vasculaires, etc. Un nombre croissant d'enquêtes démontre que divers VE conçus peuvent réparer le tissu endommagé in vivo².

Cet éditorial a mis en évidence 6 articles sélectionnés dédiés aux vésicules extracellulaires artificielles, notamment : 1) les stratégies classiques de modification des VE; 2) le rôle des VE modifiées dans le traitement. En outre, les perspectives des véhicules électriques conçus ont été brièvement discutées.

Pour améliorer l'efficacité des VE ainsi que la rétention tissulaire ciblée, plusieurs investigations ont été réalisées. Kyle et al ont d'abord utilisé un peptide spécifique des cardiomyocytes (CMP) pour fabriquer les EVs à cible cardiaque ${ }^{3}$. Il a ensuite vérifié si les EV modifiées (CMP-EV) peuvent être spécifiquement absorbées par les cardiomyocytes à la fois in vitro et in vivo. Cette approche a mis les bases de la livraison d'EV cellulaires et cardiaques spécifiques, qui fournit une référence pour l'étude d'EV ciblée. Il est intéressant de noter que Tang et al ont proposé une nouvelle idée basée sur le recrutement de plaquettes par les cellules endothéliales lésées ${ }^{4}$. Ces auteurs ont décoré des microvésicules plaquettaires (à l'intérieur des plaquettes, similaires aux VE) à la surface des cellules souches cardiaques dérivées de la cardio-sphère (CSC), ce qui a considérablement augmenté la rétention dans le coeur. Cette approche de manipulation est sûre et simple, ce qui ouvre de nouvelles perspectives sur les EV ciblées pour la thérapie. Récemment, Liming et al ont utilisé un hydrogel adhésif pour améliorer la rétention des $\mathrm{EVs}^{5}$. Les EV ont été immobilisées dans un hydrogel adhésif (Exo-pGel) et les EV encapsulées peuvent rester dans la zone lésée. L'Exo-pGel présente une stratégie prometteuse pour le traitement préclinique.

Il a été bien établi que les VE modifiées ont un grand potentiel pour le traitement des maladies dans les modèles animaux. Vandergriff et al ont systématiquement étudié le rôle des CMP-EV dans l'hydrogel adhésif. Les auteurs ont découvert que les VE conjuguées au peptide de référence cardiaque (CHP, similaire au CMP) peuvent protéger le cœur contre les lésions d'ischémie/ reperfusion en raison de leur rétention accrue ${ }^{6}$. Ce travail démontre une nouvelle approche pour augmenter la livraison du traitement de l'infarctus du myocarde. Liu et al ont rapporté que le chargement d'EV avec un nouveau complexe d'hydrogels peut favoriser la cicatrisation des plaies, ce qui fournit une autre stratégie d'hydrogel efficace pour l'ingénierie des $\mathrm{EV}^{7}$. Li et al ont étudié les rôles d'Exo-pGel dans le traitement des lésions de la moelle épinière. Il a été démontré que l'Exo-pGel favorisait de manière significative la récupération nerveuse en inhibant le stress oxydatif et l'inflammation ${ }^{5}$. En outre, Chuanjiang He et al donnent un aperçu de 
la façon dont les VE sont conçus comme des outils puissants en médecine translationnelle ${ }^{8}$.

En conclusion, il existe des stratégies pour concevoir des VE/ nanoparticules, avec des rôles potentiels dans le traitement des maladies. Notamment, davantage d'investigations précliniques et d'essais cliniques sont encore nécessaires pour élucider le potentiel des véhicules électriques et des nanoparticules dans le traitement des maladies humaines.

\section{Funding}

This work was supported by the grants from National Natural Science Foundation of China (81722008 and 81911540486 to JJ Xiao), Innovation Program of Shanghai Municipal Education Commission (2017-01-07-00-09-E00042 to JJ Xiao), the grant from Science and Technology Commission of Shanghai Municipality (18410722200 and 17010500100 to JJ Xiao), National Key Research and Development Project (2018YFE0113500 to JJ Xiao), and the „Dawn" Program of Shanghai Education Commission (19SG34 to JJ Xiao).

\section{Conflicts of Interest}

The authors declare that they have no conflict of interest.

\section{REFERENCES}

1. Menasche P, Alfieri O, Janssens S, et al. The myoblast autologous grafting in ischemic cardiomyopathy (MAGIC) trial: first randomized placebo-controlled study of myoblast transplantation. Circulation. 2008;117(9):1189-200.

2. Bjorge IM, Kim SY, Mano JF, Kalionis B, Chrzanowski W. Extracellular vesicles, exosomes and shedding vesicles in regenerative medicine - a new paradigm for tissue repair. Biomater Sci. 2017;6(1):60-78.

3. Mentkowski KI, Lang JK. Exosomes engineered to express a cardiomyocyte binding peptide demonstrate improved cardiac retention in vivo. Sci Rep. 2019;9(1):10041.

4. Tang J, Su T, Huang K, et al. Targeted repair of heart injury by stem cells fused with platelet nanovesicles. Nat Biomed Eng. 2018;2:17-26.

5. Li L, Zhang Y, Mu J, et al. Transplantation of human mesenchymal stem cell-derived exosomes immobilized in an adhesive hydrogel for effective treatment of spinal cord injury. Nano Lett. 2020. doi:10.1021/acs.nanolett.0c00929.

6. Vandergriff A, Huang K, Shen D, et al. Targeting regenerative exosomes to myocardial infarction using cardiac homing peptide. Theranostics. 2018;8(7):1869-78.

7. Wang C, Liang C, Wang R, et al. The fabrication of a highly efficient self-healing hydrogel from natural biopolymers loaded with exosomes for the synergistic promotion of severe wound healing. Biomater Sci. 2019;8(1):313-24.

8. He C, Zheng S, Luo Y, Wang B. Exosome theranostics: biology and translational medicine. Theranostics. 2018;8(1):237-55. 